\title{
ASSESSMENT OF TUBULAR LIGHT GUIDES WITH RESPECT TO BUILDING PHYSICS
}

\author{
OCENA CEVASTIH VODNIKOV SVETLOBE GLEDE NA \\ GRADBENO FIZIKO
}

\author{
František Vajkay, David Bečkovský, Vladimír Tichomirov \\ Brno University of Technology, Faculty of Civil Engineering, Institute of Building Structures, Veveři 95, 602 00 Brno, Czech Republic \\ vajkay.f@fce.vutbr.cz
}

Prejem rokopisa - received: 2013-10-01; sprejem za objavo - accepted for publication: 2015-06-08

doi:10.17222/mit.2013.204

\begin{abstract}
Architecture and the building industry consist of several minor fields, which come together when a building is designed and erected. One of them is the field of building physics. It primarily focuses on the evaluation of constructions, structures and spaces with respect to thermo-technical conditions, daylighting and many more. It is believed that among the above-mentioned sub-fields of building physics, daylighting is the most important because it influences the health of every human being. Daylighting enables people to see the colours and objects surrounding them. Therefore, buildings have to be equipped with a kind of daylighting system. In the past, spaces located either in the centres of buildings or in the underground areas were illuminated solely on the basis of luminaries. Nowadays, indirect daylighting systems like optical fibres or tubular light guides may also be utilized.

In Central Europe, the application of tubular light guides in buildings increases every year. The manufacturers say that this is an important and maintenance-free system. It is a system that brings light into any building, thus helping to save money. On the other hand, the designing of tubular light guides is complicated as it has to deal with daylighting, thermo-technical aspects and moisture. A huge amount of light guides is problematic due to the condensation of water inside the pipes, which is a side effect of a non-air-tight solution, or just due to an incorrect thermal analysis. The paper focuses on different aspects of designing light-guiding systems through computer simulations.
\end{abstract}

Keywords: tubular light guide, illuminance, luminance, building physics, computer simulations

Arhitektura in gradbeništvo sestojita iz več glavnih področij, ki se združijo, ko je objekt načrtovan in zgrajen. Eno od takih področij je gradbena fizika. To je področje, ki je usmerjeno predvsem na oceno konstrukcije, zgradbe in prostora glede na termo-tehnične pogoje, dnevno svetlobo in podobno. Med omenjenimi podpodročji gradbene fizike je najbolj pomembna dnevna svetloba, ker vpliva na zdravje vsakega človeka. Dnevna svetloba omogoča, da vidimo barve in predmete okrog sebe. Zato morajo biti zoradbe opremljene s sistemom za dnevno svetlobo. Včasih so bili prostori, locirani v sredini zgradbe ali v podzemlju, osvetljeni samo na osnovi svetlobnih teles. Danes pa lahko uporabljamo tudi posredne sisteme za dnevno svetlobo z optičnimi vlakni ali s cevastimi vodniki svetlobe.

V centralni Evropi uporaba cevastih vodnikov svetlobe v zgradbah iz leta v leto narašča. Proizvajalci trdijo, da je to pomemben sistem, ki ne potrebuje vzdrževanja. Sistem omogoča svetlobo v zgradbi, kar pomaga pri zmanjševanju stroškov. Vendar pa je načrtovanje cevastih vodnikov svetlobe zapleteno, glede na to ali gre za dnevno svetlobo ali termo-tehnično načrtovanje in vlago. Velik delež vodnikov svetlobe ima težave zaradi kondenzirane vlage znotraj cevi, kar je stranski učinek nevodotesne izvedbe ali pač samo nepravilne termične analize. Članek je usmerjen na različne vidike računalniške simulacije pri načrtovanju sistema za prevajanje svetlobe.

Ključne besede: cevast vodnik svetlobe, osvetljenost, svetilnost, gradbena fizika, računalniška simulacija

\section{INTRODUCTION}

Lighting design of indoor spaces is a rarely discussed discipline of the building industry. More often then not, it is in the shadows of the fields related to the thermotechnical processes organised in a building, ${ }^{1}$ although the light makes it possible for humans to see their surroundings, since the visible part of optical radiation (i.e., the visible light) causes certain photochemical reactions in the eye balls. The information perceived by the eye balls is then processed in the brain. ${ }^{2}$ When more light enters the eyes through the corneas we can distinguish more details of the surroundings. This property should be reflected on the daylighting design of indoor spaces as well. Human beings spend about $80 \%$ of their lives indoors and it is necessary to think about how natural light can enter a building. Usually architects use one of the available direct daylighting systems, like:

- windows and their variants,

- roof lights.

However, as we need to make buildings more compact because of land prices or we use the underground areas, architects are required to use indirect daylighting systems as well.

Representatives of these are optic-fibre systems (widely applied in the USA, but not in the EU) and tubular light guides.

Tubular light guides are a type of indirect daylighting system. Their history can be traced back to ancient Egypt, when the predecessors of light guides were used to illuminate sanctuaries. ${ }^{3}$ Only after their reinvention in the $19^{\text {th }}$ century and their further development that 
started at the end of the $20^{\text {th }}$ century, they become what they are today. ${ }^{4}$ Each light guide consists of at least three elements:

- the copula (the external cover made from a material with high light transmission),

- the tube (the pipe with a special surface finish that has a high light-reflectance value),

- the diffuser (the internal finish of light guides distributing the light).

Tubular light guides can differ in every aspect. They can have different lengths and diameters of the tube, and also different copulas and diffusers. Howbeit, once the elements ordered are assembled on a construction site and later built into the building, some issues might arise because of the unexpected physical properties of the building. One of these may be associated with the daylighting of the building since light guides are difficult to design. The other difficulty might be a result of the thermal design, as water vapour often condenses inside the pipe.

The paper is focused on the available computer tools, which can be used to monitor the resulting properties of the light guides within the selected test case.

\section{EXPERIMENTAL SECTION}

Indoor spaces in the centres of buildings or underground areas can be illuminated with indirect daylighting systems using natural light, or with luminaries. Tubular light guides already proved to be efficient in this respect, at least during daytime. The first half of this section is focused on this particular topic.

The second half of the experimental section deals with the thermo-technical simulations of the chosen tubular-light-guide system, since it passes through the envelope, especially through the roof.

The dimensions of the room assessed were $7 \mathrm{~m} \times$ $2.5 \mathrm{~m}$ and the room represented a corridor. The tubular light guides were located along the longitudinal axis of the space. The plan of the room including the light-guide positions is shown in Figure 1.

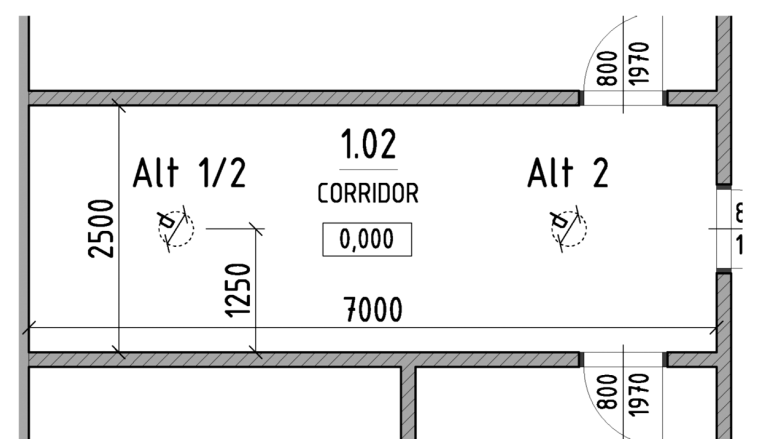

Figure 1: Plan of the corridor including the positions of designed tubular light guides

Slika 1: Načrt hodnika, ki vključuje položaj načrtovanih cevastih vodnikov svetlobe

\subsection{Daylighting design}

One of the most useful computer simulation tools is HOLIGILM. It was developed to assess the amount of the visible light transmitted by straight tubular light guides. It is simple to use, fast and it provides a graphical output. Nonetheless, it cannot evaluate the internally reflected component of daylight in the same way as Radiance or Velux Daylight Visualizer.

Although all 15 sky-type definitions described by $\mathrm{CIE}^{6}$ are implemented in HOLIGILM, considering the local codes of European countries including the Czech Republic, the simulations were done only for the CIE overcast-sky conditions. ${ }^{7}$

The properties of the tubular light guides input to HOLIGILM were as follows:

- transparency of the copula: $t_{\mathrm{c}}=95 \%$,

- surface reflectance of the pipe (Spectralight Infinity compound): $r_{\mathrm{p}}=99.7 \%$,

- transparency of the thermally insulating element dividing the pipe into two segments: $t_{\mathrm{te}}=95 \%$,

- transparency of the diffuser (to be on the safe side of the calculations): $t_{\mathrm{d}}=75 \%$.

Seeing that HOLIGILM does not have any input fields for additional light-transmitting parts like the thermally insulating element, the total light transmittance of the diffuser had to include that value as well; hence, this value was set to $71 \%$ instead of $75 \%$.

The total length $l$ of the tubular light-guide pipe is $4.5 \mathrm{~m}$ and its diameter $d$ is $0.530 \mathrm{~mm}$.

Since the space is used as a corridor two distances $\left(l_{1}\right)$ were set between the diffuser and the working plane:

- $2.15 \mathrm{~m}$ corresponding to the distance to the base location of the working plane at $0.85 \mathrm{~m}$ above the floor since in each room there may be some furniture;

- $3.0 \mathrm{~m}$ at the floor level so that the corridor is suitable for movements.

\subsection{Thermo-technical design}

Thermo-technical calculations were carried out in Agros2D. Agros2D is a free multi-platform alternative to ANSYS Workbench and COMSOL Multiphysics.

The aims were:

- to find out whether water vapour can condense within the pipe,

- to determine the point-wise thermal conductivity of the structure. ${ }^{8}$

The thermal-conductivity coefficients of the structural elements were set as follows:

- acryl: $l_{\mathrm{a}}=0.2 \mathrm{~W} \mathrm{~m}^{-2} \mathrm{~K}$,

- the thermal insulation of mineral wool around the pipe: $l_{t i 1}=0.040 \mathrm{~W} \mathrm{~m}^{-2} \mathrm{~K}$,

- the thermal insulation of mineral wool as part of the roof: $l_{\mathrm{ti} 2}=0.040 \mathrm{~W} \mathrm{~m}^{-2} \mathrm{~K}$,

- the pipe: $1_{\mathrm{p}}=0.220 \mathrm{~W} \mathrm{~m}^{-2} \mathrm{~K}$,

- steel: $l_{\mathrm{s}}=50.0 \mathrm{~W} \mathrm{~m}^{-2} \mathrm{~K}$,

- the lambda value of air depends on its volume. 


\section{RESULTS}

\subsection{Daylighting design}

It was assumed that the luminous efficacy of a tubular light guide of this length under the CIE Overcast Sky conditions would prove to be insufficient to illuminate the working plane at $0.85 \mathrm{~m}$ above the floor level. The resulting illuminance levels were rather low. The values varied from $0 \mathrm{~lx}$ to $100 \mathrm{~lx}$ (equivalent to $0 \%$ and $1 \%$ of daylight factor, Figure 2). With an additional light guide, it was possible to shift these values. For example, the minimum value grew by 40 lx (Figure 3 ).

Seeing that the design only included the sky component of the daylight factor and that the light-transmittance value of the light guide was reduced by the thermally insulating element, it can be concluded that the values were extraordinarily high. The peaks beneath the light guides, at a distance of $2.15 \mathrm{~m}$, increased by $10 \mathrm{~lx}$, from $100 \mathrm{~lx}$ to $110 \mathrm{~lx}$.

Since illuminance decreases with the increasing distance, when considering the results described previously, the evaluation at the floor level was done under the assumption that two tubular light guides should be used to illuminate the designed space.

As anticipated, the resulting light levels dropped. The peak values beneath the light guides receded to $58 \mathrm{~lx}$ (Figure 4).

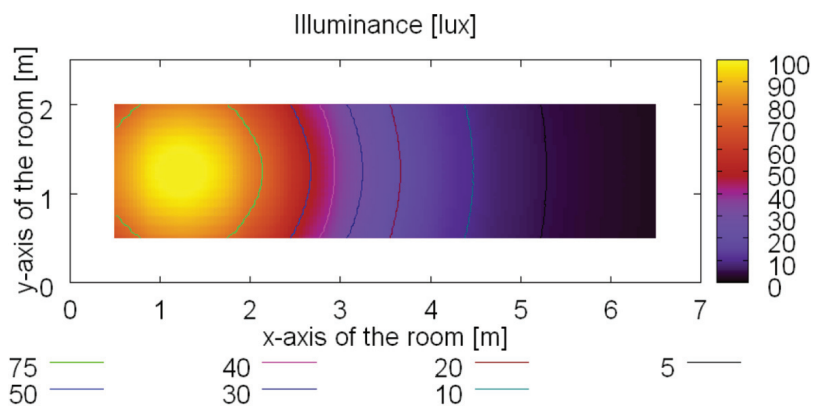

Figure 2: Illuminance-contour plot at $2.15 \mathrm{~m}$ beneath the diffuser for one tubular light guide

Slika 2: Diagram obrisa osvetljenosti pri $2,15 \mathrm{~m}$ pod difuzorjem pri enem cevastem vodniku svetlobe

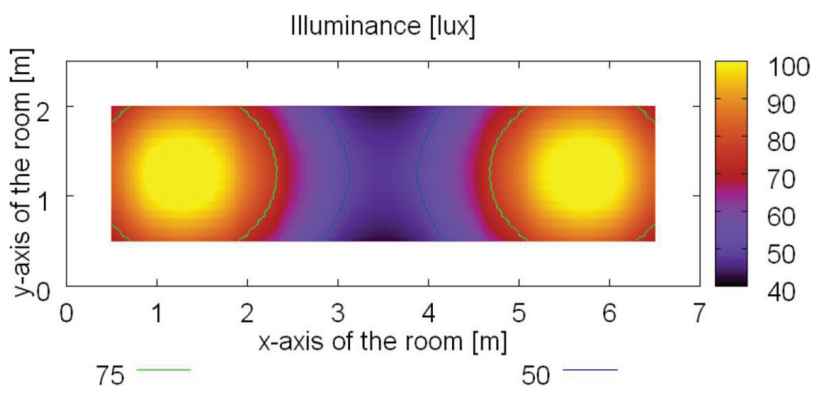

Figure 3: Illuminance-contour plot at $2.15 \mathrm{~m}$ beneath the diffuser for two tubular light guides

Slika 3: Diagram obrisa osvetljenosti pri $2,15 \mathrm{~m}$ pod difuzorjem pri dveh cevastih vodnikih svetlobe

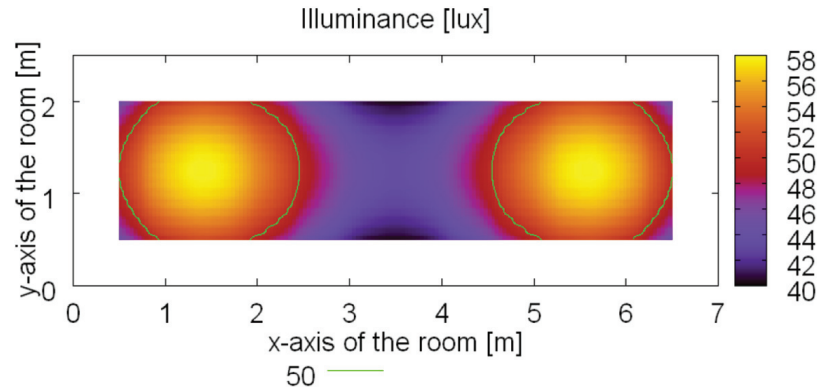

Figure 4: Illuminance-contour plot at $3.0 \mathrm{~m}$ beneath the diffuser for two tubular light guides

Slika 4: Diagram obrisa osetljenosti pri $3 \mathrm{~m}$ pod difuzorjem pri dveh cevastih vodnikih svetlobe

\subsection{Thermo-technical simulations}

The results presented on Figure 5 were obtained with the simulations provided under common boundary conditions. External and indoor air temperatures were set to $-15{ }^{\circ} \mathrm{C}$ and $20{ }^{\circ} \mathrm{C}$ and the corresponding relative air humidity inputs were $84 \%$ for the exterior and $50 \%$ for the interior.

As can be seen on Figure 5, the contact surface temperature on the interface of the light guide and the roof varies between $16{ }^{\circ} \mathrm{C}$ and $20^{\circ} \mathrm{C}$.

Other results can be connected to the overall thermal conductivity of the light pipe, which is evaluated just like in the case of windows.

The simulations pointed out that the $U$ point-wise thermal conductivity of the structure is $0.37 \mathrm{~W} \mathrm{~K}^{-1}$. This value is smaller than the one required by the Czech legislation; therefore, the light guide meets the necessary conditions.

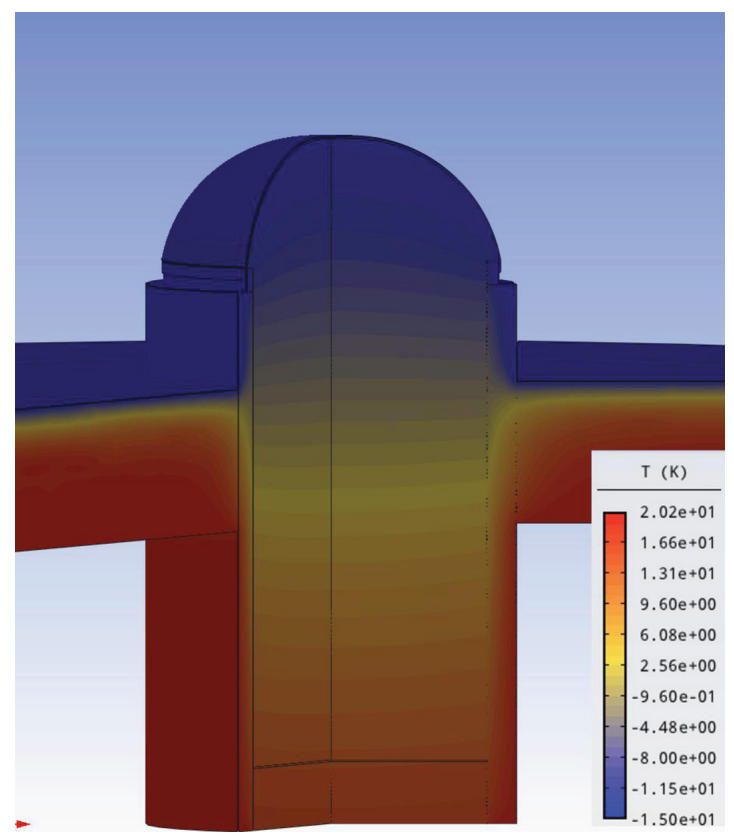

Figure 5: Temperature profile of the light guide Slika 5: Temperaturni profil vodnika svetlobe 


\section{DISCUSSION}

Tubular light guides are a type of daylighting system, used to illuminate a room or a bigger space inside a building or construction, in which natural light is hardly available. However, an emphasis should be put onto the ways a light guide can be designed with respect to daylighting, thermo-technical requirements and other factors.

The above results for daylighting were determined solely with HOLIGILM. The software can draw luminance maps for the diffuser and determine the total luminous flux beneath the optical interface. It is useful for simulations when a tubular light guide is regarded as a luminary, practically artificial light source. For the artificial-lighting design, luminaries are represented as IES data files. Light guides can also be designed in this way instead of using the approach based on a naturallight source. This approach is useful because HOLIGILM cannot determine the internally reflected component of the daylight factor, but only the sky component. Another disadvantage of HOLIGILM is that the room used can only have a rectangular shape. On the contrary, when the internally reflected component of the daylight factor is neglected, the results may be obtained for rooms of any shape. However, simulations for different sky types created by the software tools using one of the global illumination models can be important in future since the use of photorealistic rendering slowly but steadily rises year by year.

As for the thermo-technical design of light guides, it can be said that they lack one crucial parameter. That is the motion of the air inside and outside the pipe. The pipe is commonly manufactured from plain metal sheets, thus, when put together, the joints are not sealed by sealants. Therefore, at some places, there can be leakage of air, with a possibility of water vapour entering the light-guiding system. This water can condense inside the pipe at any time, especially in winter. The condensed water may damage the surrounding structures. Also, the fact that the thermal conductivity of the resulting structure can be evaluated just because it goes through the envelope of a building leaves some space for improvements. Another approach similar to that of the determination of the thermal conductivity may or may not be correct and should be researched in detail via long-term monitoring, not just by the means of computer simulations.

\section{CONCLUSION}

The design and application of tubular light-guiding systems have a flaw: most of their parameters regarding building physics are determined solely by computer simulations, which are not required to correspond to reality.

This could be changed by the means of experimental activities, which are planned within the Faculty of Civil Engineering. Through a comprehensive long-term monitoring, several characteristics could be observed, such as the movement of the air in the pipe, temperature rises and the effects of air humidity in the light guides.

\section{Acknowledgement}

This paper was prepared within project No. LO1408 "AdMaS UP - Advanced Materials, Structures and Technologies", supported by the Ministry of Education, Youth and Sports under National Sustainability Programme I.

\section{REFERENCES}

${ }^{1}$ P. Charvat, T. Mauder, M. Ostry, Simulation of Latent-Heat Thermal Storage Integrated with Room Structures, Mater. Tehnol., 46 (2012), 239-242

${ }^{2}$ P. Boyce, P. Raynham, SLL Lighting Handbook, CIBSE, London 2009

${ }^{3}$ F. Moore, Concepts and Practice for Architectural Daylighting, Van Nostrand Reinhold, New York 1985, 290

${ }^{4}$ J. Mohelnikova, F. Vajkay, Study of Tubular Light Guides Illuminance Simulations, LEUKOS, 5 (2009), 267-277, doi:10.1582/ LEUKOS.2008.05.04.001

${ }^{5}$ M. Kocifaj, S. Darula, R. Kittler, HOLIGILM: Hollow light guide interior illumination method - An analytic calculation approach for cylindrical light-tubes, Solar Energy, 82 (2008) 3, 247-259, doi:10.1016/j.solener.2007.07.003

${ }^{6}$ Commission Internationale de l'Eclairage, CIE DS 011.2/E: 2002 Spatial distribution of daylight - CIE standard general sky, Vienna: Commission Internationale de l'Eclairage, 2002

${ }^{7}$ Czech Standardization Institute, ČSN 730580 Daylighting in buildings - Part 1: Basic Requirements, Prague, Czech Standardization Institute, 2007

${ }^{8}$ Czech Standardization Institute, ČSN 730540 Thermal protection of buildings - Parts 1,2,3,4 Prague, Czech Standardization Institute, 2005 and 2011 